\title{
Release of intact, monomeric cytochrome $c$ from apoptotic and necrotic cells
}

\author{
R Jemmerson ${ }^{*, 1}$, B LaPlante ${ }^{1}$ and A Treeful ${ }^{1}$ \\ ${ }^{1}$ Department of Microbiology and Center for Immunology University of \\ Minnesota Medical School Minneapolis, MN 55455, USA \\ * Corresponding author: R Jemmerson, Mayo Mail Code 196, Fairview- \\ University Medical Center, University of Minnesota, 420 Delaware St. S.E., \\ Minneapolis, MN 55455, USA; Tel: 612-625-1402; Fax: 612-626-0623; \\ E-mail: ron@lenti.med.umn.edu
}

Received 27.3.01; revised 6.8.01; accepted 8.11.01 Edited by $\mathrm{G}$ Salvesen

\begin{abstract}
Cytochrome $c$ (Cyt $c$ ) has been shown to translocate from mitochondria to the cytoplasm of cells early in apoptosis. In this study sandwich ELISAs for Cyt $c$ were used to determine if Cyt $c$ is ultimately released from apoptotic and necrotic cells. Gel-filtration and cation-exchange chromatographies, in conjunction with immunoreactivity in ELISA, and Western blotting were employed to examine the integrity of the released Cyt $c$. The results show that Cyt $c$ is released from both apoptotic and necrotic cells in an intact, monomeric form. The release of Cyt $c$ from apoptotic splenocytes began within $2 \mathrm{~h}$ following apoptotic insult, while Cyt $c$ was immediately released following induction of necrosis by heat shock. These findings may be relevant to understanding how Cyt $c$ becomes a target for antibody production in some patients with systemic autoimmune diseases.

Cell Death and Differentiation (2002) 9, 538-548. DOI: 10.1038/ sj/cdd/4400981
\end{abstract}

Keywords: cytochrome $c$; apoptosis; necrosis; systemic autoimmunity

Abbreviations: Cyt $c$, cytochrome $c$; ELISA, enzyme-linked immunoadsorbent assay; FACS, fluorescence-activated cell scanning; HPLC, high-performance liquid chromatography; LDH, lactate dehydrogenase; mAb, monoclonal antibody; SLE, systemic lupus erythematosus

\section{Introduction}

Cytochrome $c$ (Cyt $c$ ), an electron transport protein normally residing between the inner and outer mitochondrial membranes, ${ }^{1,2}$ has been shown to translocate from mitochondria to the cytoplasm in apoptosis. ${ }^{3-5}$ In the cytoplasm Cyt $c$ serves as a co-factor in Apaf-1 (apoptotic protease activating factor-1)-mediated activation of caspase-9. ${ }^{3,6}$ Subsequently, Cyt $c$ disappears from late apoptotic cells as visualized by immunofluoresence and Western blots of cytosolic extracts. ${ }^{7,8}$ While this has been reported for neuronal cells, it appears to occur in other cells as well. For example, we have observed that some post-apoptotic transformed myelocytic cells (HL-60) fail to react with anti-Cyt c mAbs by immunofluorescence and other cells in the same preparation show decreased intensities of immunofluorescence (unpublished results). These observations have been interpreted to mean that Cyt $c$ is ultimately degraded in apoptotic cells. ${ }^{7,8}$ However, it is not clear that Cyt $c$ may be altered in some way that affects its detection by immunological methods or may be released from cells late in apoptosis, like some other molecules including cytoplasmic proteins and nuclear components. ${ }^{9-11}$

To examine these possibilities commercially-available sandwich ELISAs were used to quantify Cyt $c$ in the extracellular fluid from death-induced cultures of two transformed cell lines, a pro-myelocytic leukemia of human origin (HL-60) and a mouse T hybridoma, as well as from cultured mouse and rat splenocytes. The effects of apoptotic and necrotic insults on these cells were compared. The results show that Cyt $c$ is released from both apoptotic and necrotic cells in an intact, monomeric form. Thus, Cyt $c$ which was previously shown to elicit antibodies in systemic autoimmune diseases ${ }^{12}$ e.g., systemic lupus erythematosus (SLE), joins other antigens which are linked to these diseases, including ribonucleoproteins, histones, and DNA, as an intracellular molecule that is released from dying cells. ${ }^{9-11}$ The rapid release of Cyt $c$ from cells during severe necrosis or from apoptotic cells in the context of defects impeding phagocytosis ${ }^{13}$ may be the basis for targeting of Cyt $c$ (and other intracellular antigens) by $B$ cells and their antibodies in systemic autoimmunity.

\section{Results}

\section{Release of Cyt $c$ from post-apoptotic and necrotic} transformed cells

To examine whether Cyt $c$ is released from death-induced transformed cells sandwich ELISAs were performed using fluids from cultures of cells at various times after induction of apoptosis or necrosis. Cyt $c$ was quantified from a standard curve using purified Cyt $c$ supplied in the commercial ELISA kits for human and rat/mouse Cyt $c$. Human Cyt $c$ was assayed in the culture fluid of $\mathrm{HL}-60$ cells after induction of apoptosis by staurosporine or $\gamma$-irradiation and after induction of necrosis by heating to $65^{\circ} \mathrm{C}$ for $5 \mathrm{~min}$. Mouse Cyt $c$ was assayed in the culture fluid of T hybridoma cells after induction of apoptosis by dexamethasone or $\gamma$-irradiation and after induction of necrosis by heat shock.

Irrespective of the agent used to induce apoptosis or the species of the transformed cell or whether death was by apoptosis or necrosis, Cyt $c$ was consistently observed in the culture fluid supernate of death-induced cells as shown 


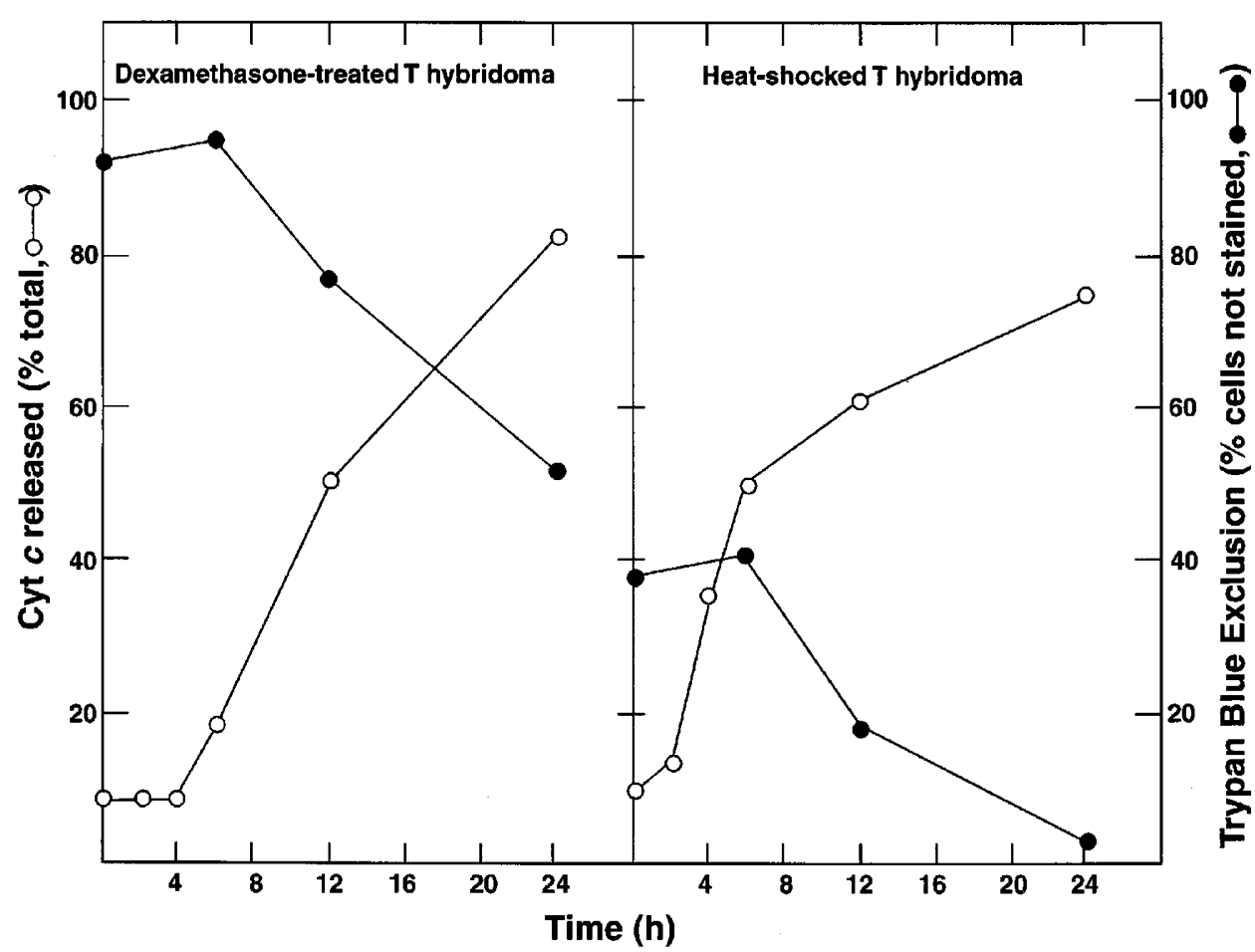

Figure 1 Release of mouse Cyt $c$ from apoptotic and necrotic T hybridoma cells in vitro. To induce apoptosis cells were treated with dexamethasone and to induce necrosis cells were heat shocked. Data points represent averages of duplicate values. The amount of Cyt c extracted from viable T hybridoma cells using detergent was approximately $110 \mathrm{ng} / 10^{6}$ cells

in Figure 1 for mouse $T$ hybridoma cells induced to apoptose by dexamethasone treatment and to undergo necrosis by heat shock. For the apoptotic cells, Cyt $c$ began to appear in the culture fluid between 4 and $6 \mathrm{~h}$ after the initiation of culture. At this time there was no decrease in cell viability as determined by the uptake of trypan blue. Since this dye has a lower molecular weight than Cyt $c$ (961 Da versus $12500 \mathrm{Da}$ ), the results suggest selective permeability of the apoptotic cells to Cyt $c$ (and, perhaps, other intracellular molecules) during this brief period (4$6 \mathrm{~h}$ ), while the cells remained impermeable to trypan blue uptake. After $6 \mathrm{~h}$ the increased release of Cyt $c$ occurred concomitantly with increased uptake of trypan blue which is indicative of necrosis. At $24 \mathrm{~h}, 83 \%$ of the Cyt $c$ was released from post apoptotic $\mathrm{T}$ hybridoma cells based on the Cyt $c$ released from viable cells by detergent-mediated lysis.

The release of Cyt $c$ from apoptotic $T$ hybridoma cells began soon after perturbations in the plasma membrane detected by annexin $\mathrm{V}$ binding and FACS as shown in Figure 2. Annexin $\mathrm{V}$ binding was first observed at $4 \mathrm{~h}$ following the initiation of treatment with dexamethasone. At $11.5 \mathrm{~h}$ a population of cells appeared with high binding capacity for annexin $\mathrm{V}$ which is indicative of necrotic cells and consistent with the trypan blue exclusion data (Figure $1)$. Thus, secondary necrosis is likely responsible for the release of Cyt $c$ at later times ( $>6 \mathrm{~h}$ ).

After heat shock the $\mathrm{T}$ hybridoma cells only gradually released Cyt $c$ despite the failure of most cells to exclude trypan blue at the initiation of culture (Figure 1). After $6 \mathrm{~h}$ increased release of Cyt $c$ occurred concomitantly with the uptake by the cells of trypan blue.

Similar kinetics for the release of Cyt $c$ were observed in the study of HL-60 cells (results not shown). It should be noted that the release of Cyt $c$ from death-induced cells was observed whether or not the cells were cultured in $15 \%$ fetal bovine serum. However, an unknown component in serum does interfere with the quantification of Cyt $c$ in sandwich ELISA so that the amount of Cyt $c$ released into the culture fluid was underestimated (results not shown). To avoid this complication, the data presented were obtained using cells cultured without serum.

The Cyt $c$ released from post-apoptotic and necrotic cells was soluble and not part of a super-molecular complex e.g., blebs from apoptotic bodies, since it passed through a 0.2 micron filter prior to detection in the ELISA (results not shown) and eluted as monomeric Cyt $c$ in gel-filtration chromatography (see below).

\section{Cyt $c$ was released from death-induced transformed cells as an intact, monomeric protein}

To examine the integrity of Cyt $c$ released from death-induced transformed cells, Cyt $c$ in the culture fluid was isolated on the basis of both size and electrical charge. Since anti-Cyt $c$ mAbs are conformationally-dependent, ${ }^{14,15}$ they were used in indirect ELISA to detect native-like Cyt $c$. For these analyses, serum was eliminated from the tissue culture medium so that Cyt $c$ could be more readily detected than when in the presence of excess serum proteins. 

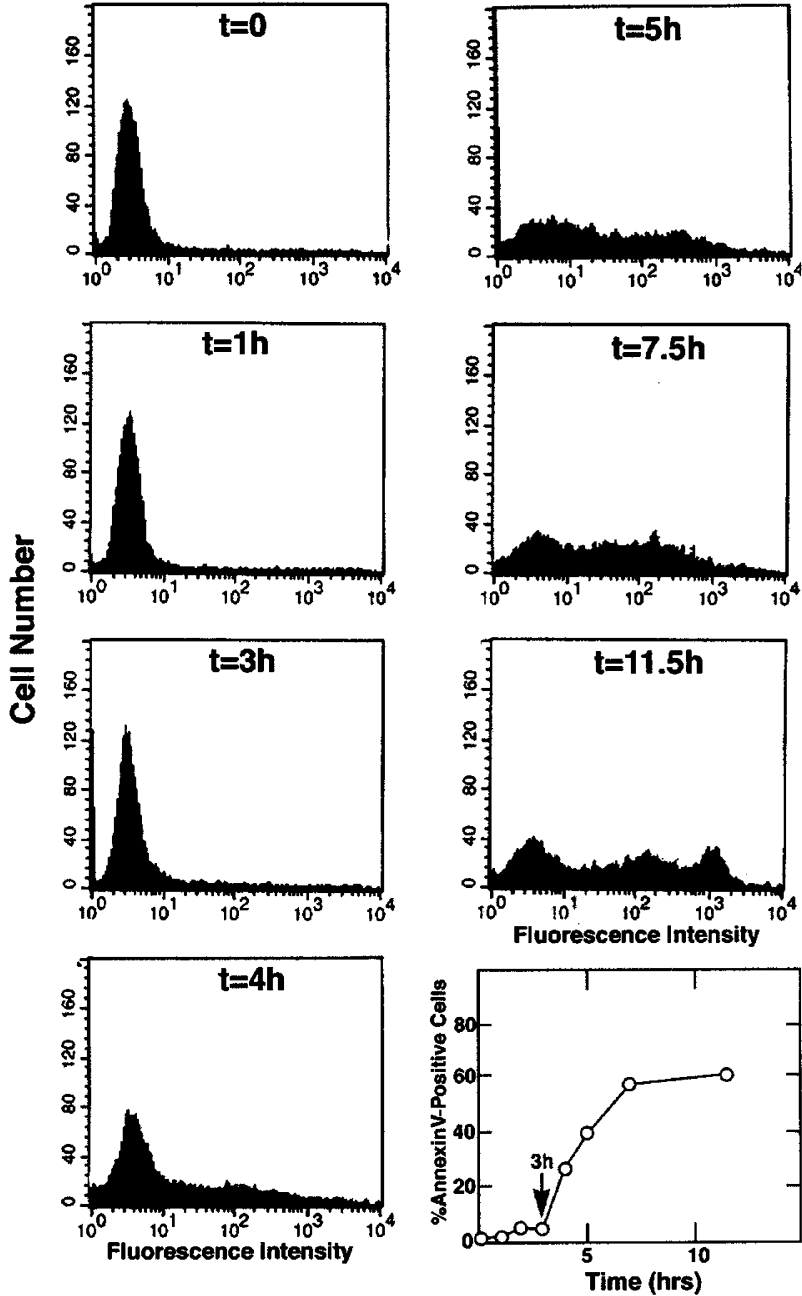

Figure 2 Annexin $\mathrm{V}$ staining of $\mathrm{T}$ hybridoma cells at various times after induction of apoptosis by dexamethasone treatment. Cells $\left(5 \times 10^{5}\right)$ were incubated with Alexa 488-Annexin V and fluorescence was detected by FACS

Sephadex G-100 was employed to fractionate components in the culture fluid on the basis of their size. Gelfiltration chromatography, unlike Western blotting, allows for the retention of native conformation which can be assessed by $\mathrm{mAb}$ binding. It is also useful for determining if a protein is aggregated or in a complex. Aliquots of fractions eluting from the gel-filtration column were adsorbed to microtiter wells and the binding of several anti-Cyt $c$ mAbs was detected by indirect ELISA. Standard proteins used to calibrate the column included immunoglobulin (m.w. 150 000), hemoglobin (m.w. 64500 ), and Cyt $c$ (m.w. $12500)$. The Cyt $c$-immunoreactive fractions from both the necrotic (heat-shocked) and post-apoptotic ( $\gamma$-irradiated) HL-60 cells corresponded to the appropriate size for intact, monomeric Cyt $c$ (Figure 3). To confirm that the gel filtration column could separate Cyt $c$ from smaller molecules, phenol red (m.w. 355) was passed through the column. It eluted later than Cyt $c$ (between fractions 85 and 110; not shown in Figure 3).

The anti-Cyt $c \mathrm{mAb}$ that were employed in these assays recognize three different epitopes: mAb 2G8.B6 binds in the region around residue $62,{ }^{15} \mathrm{mAb} 1 \mathrm{G} 1 . \mathrm{E} 9$ (mouse Cyt $c$ ) or mAb 2B5.F8 (human Cyt $c$ ) bind in the region around residue $44,{ }^{14}$ and $\mathrm{mAb} 7 \mathrm{H} 8.2 \mathrm{C} 12$ binds to the carboxyl terminal segment containing residues $93-104 .{ }^{16}$ The latter mAb reacts with non-native Cyt $c$ that appears in the ELISA wells when some native molecules denature upon attachment. mAb $7 \mathrm{H} 8.2 \mathrm{C} 12$ should detect any fragments of Cyt $c$ containing amino acids 93-99 since that is the minimal epitope recognized by this mAb. ${ }^{16}$

In addition to the reactivity with mAb 2G8.B6 and $7 \mathrm{H} 8.2 \mathrm{C} 12$ (Figure $3 \mathrm{~A}$ ), the Cyt $c$ containing fractions of post-apoptotic and necrotic HL-60 supernates also reacted with mAb 2B5.F8 (result not shown). There was a higher molecular weight component in the culture fluid of necrotic HL-60 cells (fractions 25-45) which reacted with mAb 7H8.2C12, a mAb specific for non-native Cyt $c$ (Figure $3 \mathrm{~A}$ ). The identification of this higher molecular weight component is unknown. It could represent an altered form of Cyt $c$ or some other molecule that cross-reacts with mAb 7H8.2C12. Such a molecule has been observed in Western blots of cytosolic extracts. ${ }^{3}$

Similar results (not shown) were observed in the analysis of the culture fluid of death-induced $T$ hybridoma cells, although the high molecular weight component reactive with $\mathrm{mAb} 7 \mathrm{H} 8.2 \mathrm{C} 12$ was not observed. The Cyt $c$ released from post-apoptotic $T$ hybridoma cells reacted with $\mathrm{mAb}$ 2G8.B6 and also reacted with mAb 1G1.E9 which recognizes a distinct epitope on native Cyt $c$.

To confirm that the Cyt $c$ released from post-apoptotic and necrotic transformed cells is the same size as native Cyt $c$, supernates obtained as described above were electrophoresed in polyacrylamide gels in sodium dodecylsulfate and a blot of the gel was probed with $\mathrm{mAb}$ 7H8.2C12 (Figure 3B). The Cyt $c$ released from postapoptotic and necrotic HL-60 cells was identical in size to human and rat (mouse) Cyts $c$. The Cyt $c$ released from post-apoptotic and necrotic $T$ hybridoma cells was also identical in size to native Cyt $c$ (not shown).

Besides the identity to native Cyt $c$ based on size, Cyt $c$ released from post-apoptotic and necrotic cells is identical in charge to native Cyt $c$ as determined by cation-exchange HPLC. Fractions corresponding to native, intact human Cyt $c$ were obtained from the culture fluids of both postapoptotic and necrotic HL-60 cells as shown by their reactivity with an anti-Cyt $\mathrm{c}$ mAb in indirect ELISA (Figure 3C). Similar results were observed in the analysis of supernates of post-apoptotic and necrotic $T$ hybridoma cell culture fluids (not shown).

\section{Release of intact Cyt $c$ from apoptotic and necrotic splenocytes}

Splenocytes (mostly lymphocytes) pooled from four female $\mathrm{BALB} / \mathrm{C}$ mice or obtained from a single male rat were heat shocked at $65^{\circ} \mathrm{C}$ for $5 \mathrm{~min}$ to induce necrosis or serumdeprived to induce apoptosis. Cells $\left(\sim 4 \times 10^{8}\right)$ were cultured for $16 \mathrm{~h}$ in serum-free medium. The culture supernates were dialyzed and lyophilized, as described above in the study of Cyt $c$ released from transformed cells, and analyzed by gel filtration chromatography on 
A.

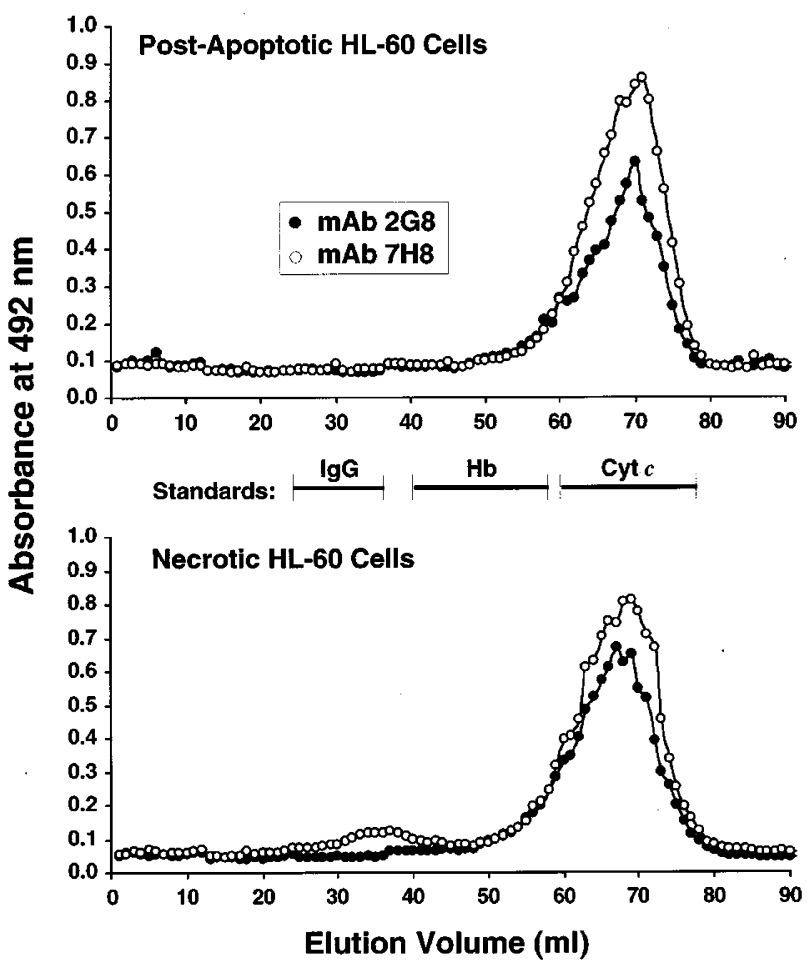

B.

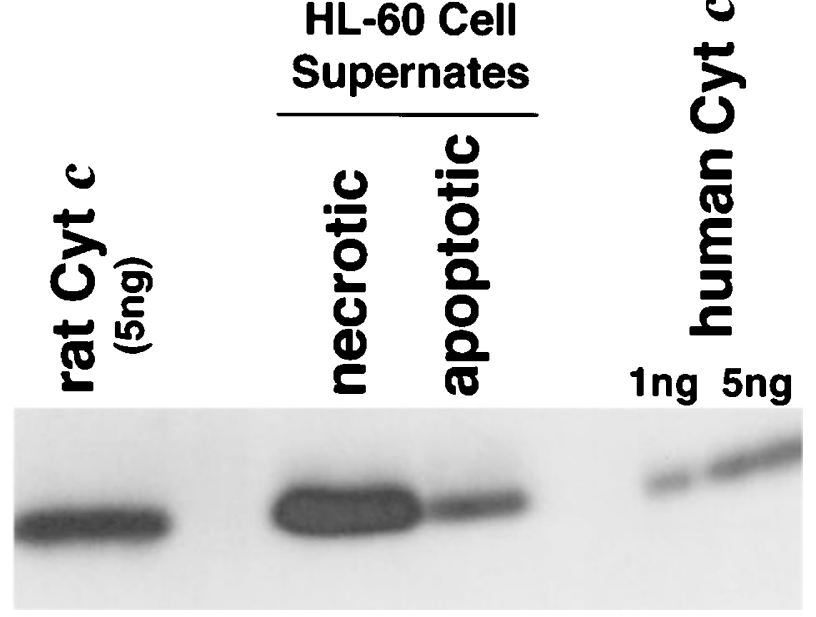

C.

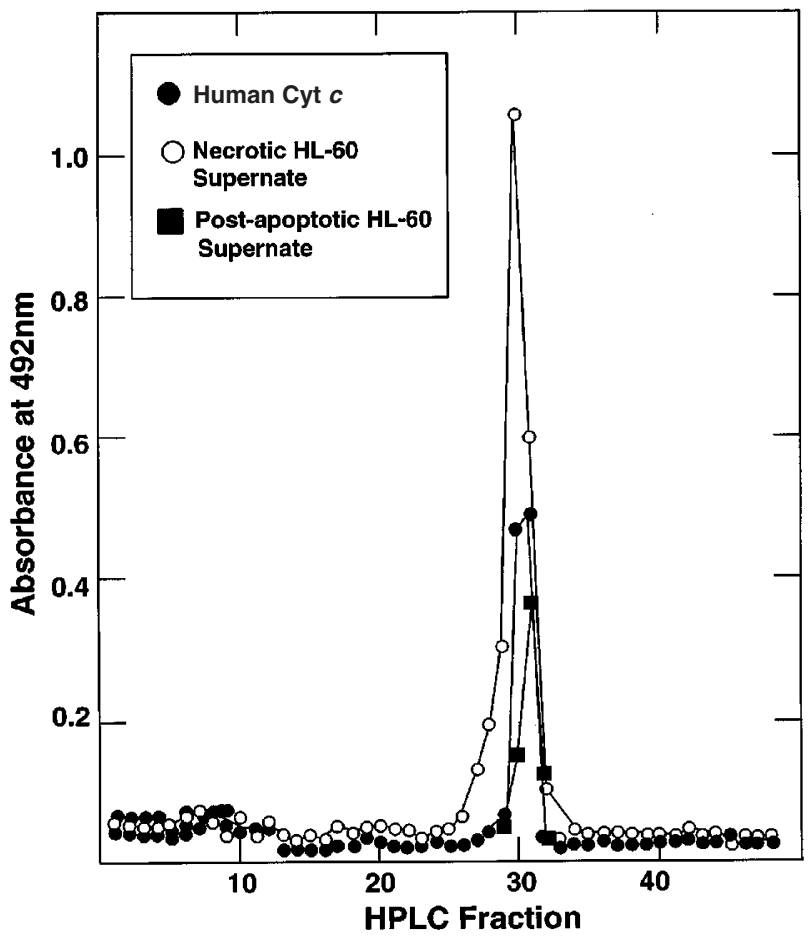

Figure 3 Cyt $c$ released from apoptotic and necrotic HL-60 cells is native and monomeric. (A) Gel filtration chromatography of Cyt $c$ released from post-apoptotic and necrotic HL-60 cells. Following death induction (see Materials and Methods) the cells were cultured in serum-free medium for $16 \mathrm{~h}$. The culture fluid supernates were dialyzed, lyophilized, and applied to a $1.5 \times 50 \mathrm{~cm}$ sephadex G-100 column. Cyt $c$-containing fractions were detected by indirect ELISA. The molecular weights of the standards used for calibration of the column were: 150000 (IgG or immunoglobulin G), 64500 (Hb or hemoglobin), and 12500 (Cyt $c$ ). Phenol red (m.w. 355 ) eluted in fractions 85 through 110 (not shown). (B) Western blots of Cyt $c$ released from post-apoptotic and necrotic HL-60 cells using mAb $7 \mathrm{H} 8.2 \mathrm{C} 12$. The results show that the size of the Cyt $c$ released from HL-60 cells is identical to intact Cyt $c$. (C) Cation-exchange chromatography of Cyt $c$ released from post-apoptotic and necrotic HL-60 cells and detection of the chromatographed protein by ELISA. Culture fluid supernates were processed as described above, applied to a $7.5 \times 75 \mathrm{~mm}$ sulfopropyl column, and eluted in a gradient of 0 to $400 \mathrm{mM}$ sodium chloride in $10 \mathrm{mM}$ sodium phosphate, pH 7.0 with a flow rate of $1.0 \mathrm{ml}$ per min

Sephadex G-100. Cyt c-containing fractions were detected by indirect ELISA. Results obtained with the mouse splenocytes are shown in Figure 4A. Similar results were observed with rat splenocytes (results not shown). The anti-Cyt $c$ immunoreactive fractions for Cyt $c$ released from both post-apoptotic and necrotic cells correlated with intact, monomeric Cyt $c$. Fractions 25-37 contained mouse IgG, secreted by splenic plasma cells. These higher molecular weight fractions, but not the lower molecular weight fractions eluting as Cyt $c$, were detected in the ELISA in the absence of the anti-Cyt $c$ mAb i.e., they reacted directly with the secondary antibody (anti-mouse IgG 
conjugated to horseradish peroxidase; not shown). The Cyt $c$-containing fractions reacted with $\mathrm{mAb}$ 2G8.B6, mAb 1G1.E9 (not shown), and $m A b 7 \mathrm{H} 8.2 \mathrm{C} 12$ in this assay.

Western blotting of Cyt $c$ present in the supernates of post-apoptotic and necrotic mouse splenocytes confirmed its identity in size to intact rat (mouse) Cyt $c$ (Figure 4B).

The integrity of Cyt $c$ released from apoptotic and necrotic splenocytes was also examined by cation-exchange HPLC (Figure 4C). The Cyt $c$-immunoreactive species released from both apoptotic and necrotic splenocytes eluted from the HPLC column identically to native Cyt c. The early eluting fractions $(2-4)$ contained mouse IgG which reacted directly with the secondary antibody in the indirect ELISA.

\section{Cyt $c$ was released relatively rapidly from death- induced apoptotic and necrotic splenocytes}

Since phagocytes effectively engulf apoptotic and necrotic cells in vivo, the time course of Cyt $c$ release from death- induced cells is important to assess whether this release may be physiologically relevant. If Cyt $c$ release in vitro occurs late in apoptosis and necrosis, it would seem unlikely that its release from death-induced cells would be of any consequence in vivo. The time courses for Cyt $c$ release from apoptotic and necrotic splenocytes are shown in Figure 5. Cyt $c$ was immediately detectable in the supernate of heatshocked (necrotic) mouse splenocytes and reached near maximal levels after several hours. Serum deprivation (apoptosis induction) led to the release of Cyt $c$ as early as 1.5-2 h (Figure 5, Exp. 2). The released Cyt $c$ measured in Exp.2 (Figure 5) at $1.5 \mathrm{~h}$ from apoptotic cells $\left(\mathrm{A}_{492 \mathrm{~nm}}=0.151 \pm 0.005\right)$ and at $2 \mathrm{~h}\left(\mathrm{~A}_{492 \mathrm{~nm}}=0.174 \pm 0.007\right)$ were significantly above the background measurement $(0.118$ and 0.115 observed at 0 and $1 \mathrm{~h}$, respectively). Thus, the release of Cyt $c$ as early as $1.5-2 \mathrm{~h}$ from apoptotic splenocytes is significant. Cyt $c$ continued to be released over the course of a day and was still approaching the maximum at $22-23 \mathrm{~h}$. Results similar to these were obtained in three other experiments e.g., as shown in Figures 7 and 8.
A.

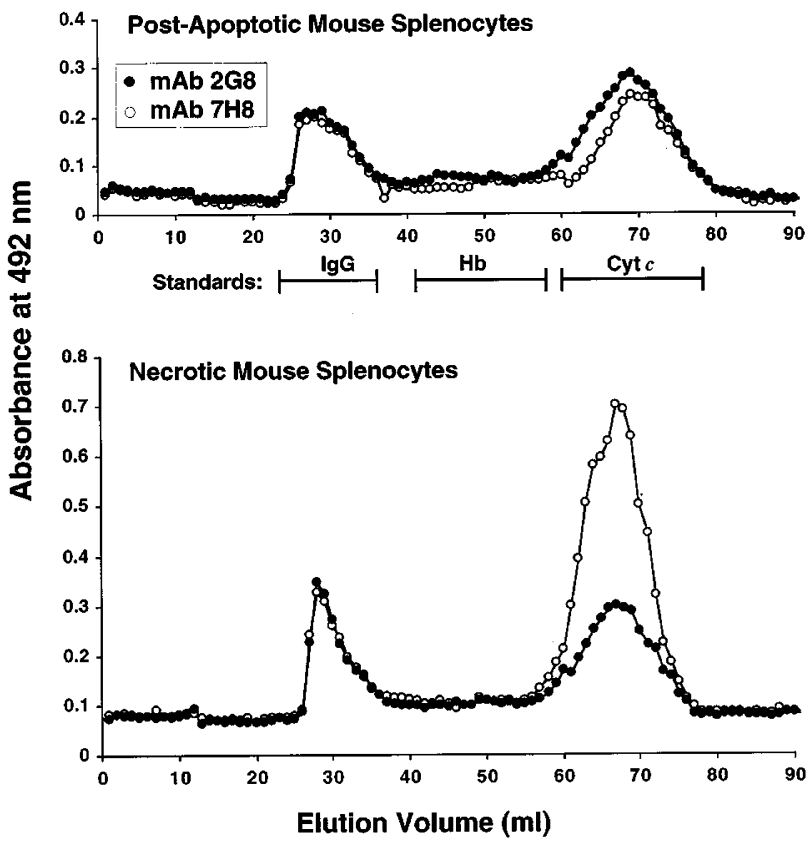

B.

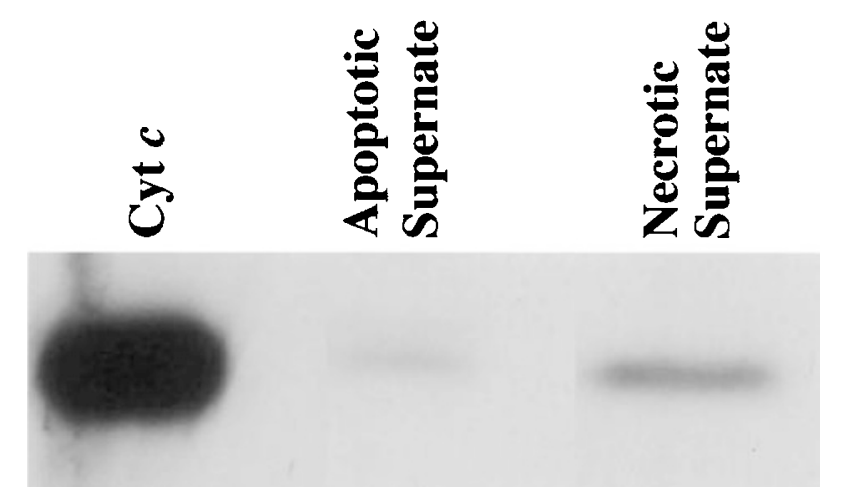

C.

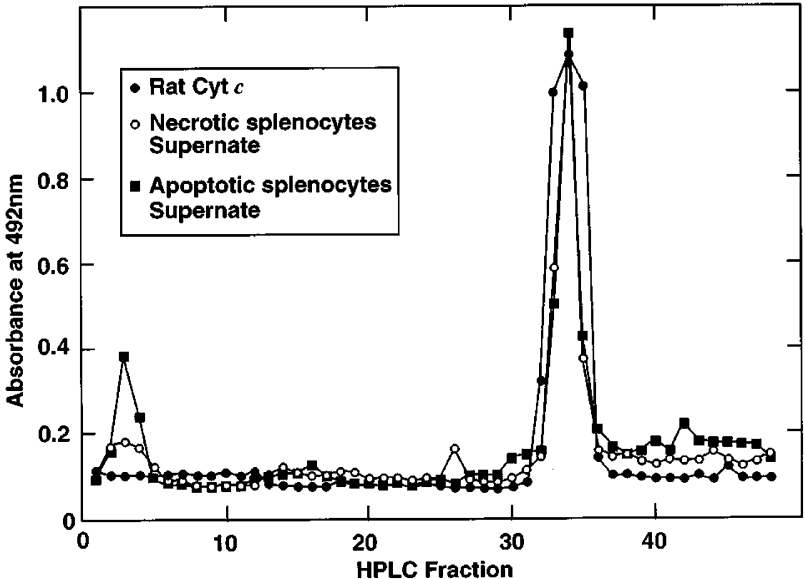

Figure 4 Cyt $c$ released from apoptotic and necrotic mouse splenocytes is intact and monomeric. Supernates from cultures of death-induced splenocytes were examined by gel filtration chromatography employing (A) Sephadex G-100, (B) Western blotting using mAb 7H8.2C12 as probe, and (C) cation-exchange HPLC employing a sulfopropyl column. In $\mathbf{A}$ and $\mathbf{C}$ the supernates were obtained from $16 \mathrm{~h}$ cultures and in $\mathbf{B}$, the supernates were obtained from $24 \mathrm{~h}$ cultures. In $\mathbf{A}$, the higher molecular weight peak represents mouse IgG which reacts with the horseradish-peroxidase-labeled secondary antibody and does not react with the anti-Cyt $c$ mAbs. The apparent difference in the sensitivity of mAb $7 \mathrm{H} 8.2 \mathrm{C} 12$ to Cyt $c$ of necrotic and apoptotic cells is apparently due to different batches of mAb used in the two assays and not to a distinction in the Cyts $c$ 


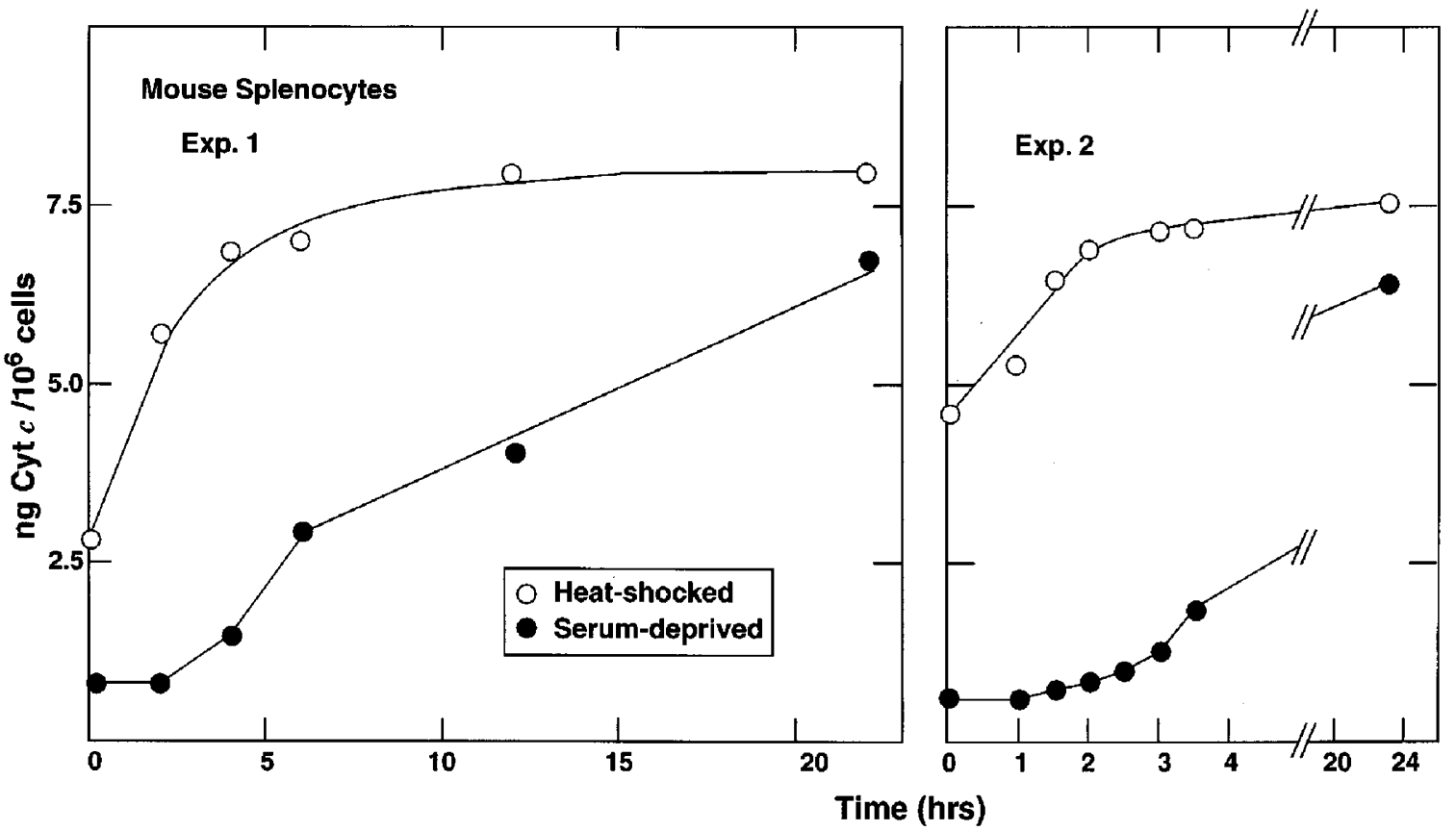

Figure 5 Time course of Cyt $c$ release from apoptotic and necrotic mouse splenocytes. Apoptosis was induced by serum deprivation and necrosis was induced by heat shock. Cyt $c$ was detected in the supernates of death-induced cultures by sandwich ELISA. The results of two separate experiments are shown. In Exp. 2, the discontinuous curve for apoptotic cell supernate was drawn based on data not shown in the graph i.e., $3.1 \mathrm{ng}$ Cyt $c / 10^{6}$ cells at $6 \mathrm{~h}$ and $5.2 \mathrm{ng}$ Cyt $c / 10^{6}$ cells at $12 \mathrm{~h}$. The total Cyt $c$ in mouse splenocytes was approximately $9 \mathrm{ng} / 10^{6}$ cells in these experiments

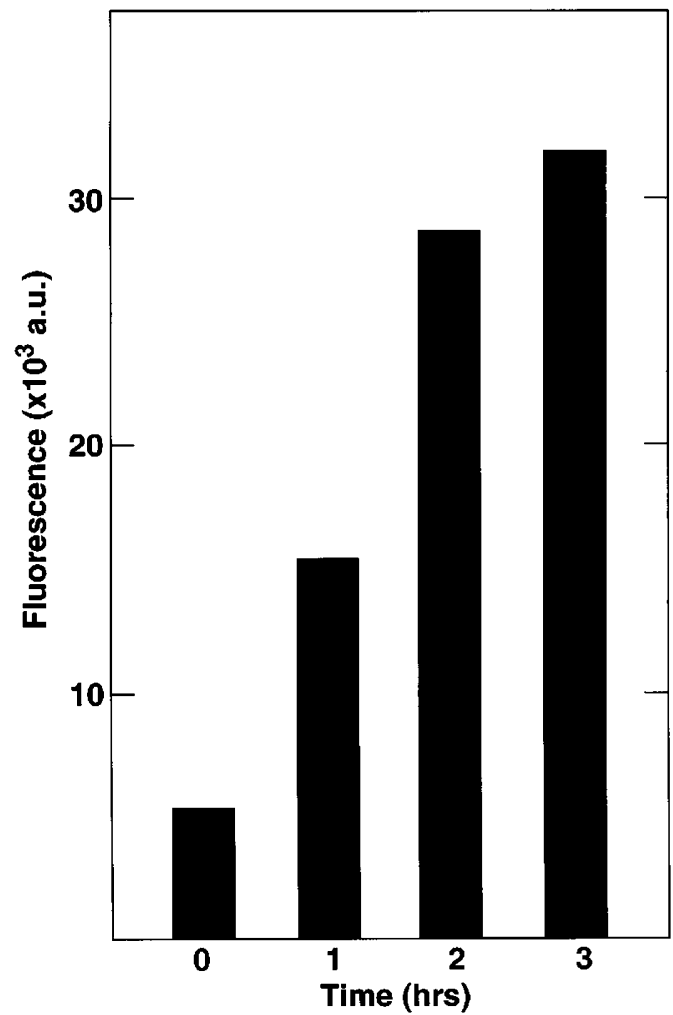

Figure 6 Caspase-3 activity in serum-deprived mouse splenocytes at various times after serum deprivation. The values given are averages of duplicate assays. The activity increased prior to the release of Cyt $c$ from the cells and was not yet maximal when Cyt $c$ was first detected in the culture fluid supernate at $1.5 \mathrm{~h}$. (see Figure 7, Exp. 2). Intracellular caspase-3 activity declined after $3 \mathrm{~h}$ (not shown)
(Note that due to the smaller size of normal splenocytes compared to transformed cells and, therefore, fewer mitochondria, less Cyt $c$ was released from the splenocytes than the transformed cells. Variations in the amount of Cyt $c$ extracted from different cell lines have been noted in the ELISA kit instructions.)

Similar results were observed when splenocytes where depleted of erythrocytes by lysis or by centrifugation through Histopaque-1077 (results not shown) indicating that the method of splenocyte preparation did not affect the rate of Cyt $c$ release.

Quantification of cells by trypan blue staining indicated that $60-70 \%$ of the splenocytes were necrotic immediately following heat treatment. In contrast, less than $5 \%$ of the serum-deprived (apoptotic) splenocytes (probably viable monocytes) stained with trypan blue at the early time points ( $6 \mathrm{~h}$ and earlier) and at $12 \mathrm{~h} 15-20 \%$ of the cells were stained in different experiments. By $24 \mathrm{~h} 40-60 \%$ of the serum-deprived splenocytes were stained with trypan blue. Thus, Cyt $c$ release from apoptotic cells beginning at 1.5$2 \mathrm{~h}$ was observed long before the plasma membrane became detectably permeable by the small molecule trypan blue (later than $6 \mathrm{~h}$ ).

\section{Cyt $c$ release from apoptotic splenocytes began after caspase-3 activation}

Several unsuccessful attempts were made to determine, using annexin $\mathrm{V}$ binding, ${ }^{17,18}$ at what time after apoptotic insult plasma membrane perturbations occurred in the splenocytes. The use of annexin $\mathrm{V}$ as an apoptosis tool for mouse lymphocytes is complicated by the fact that a 


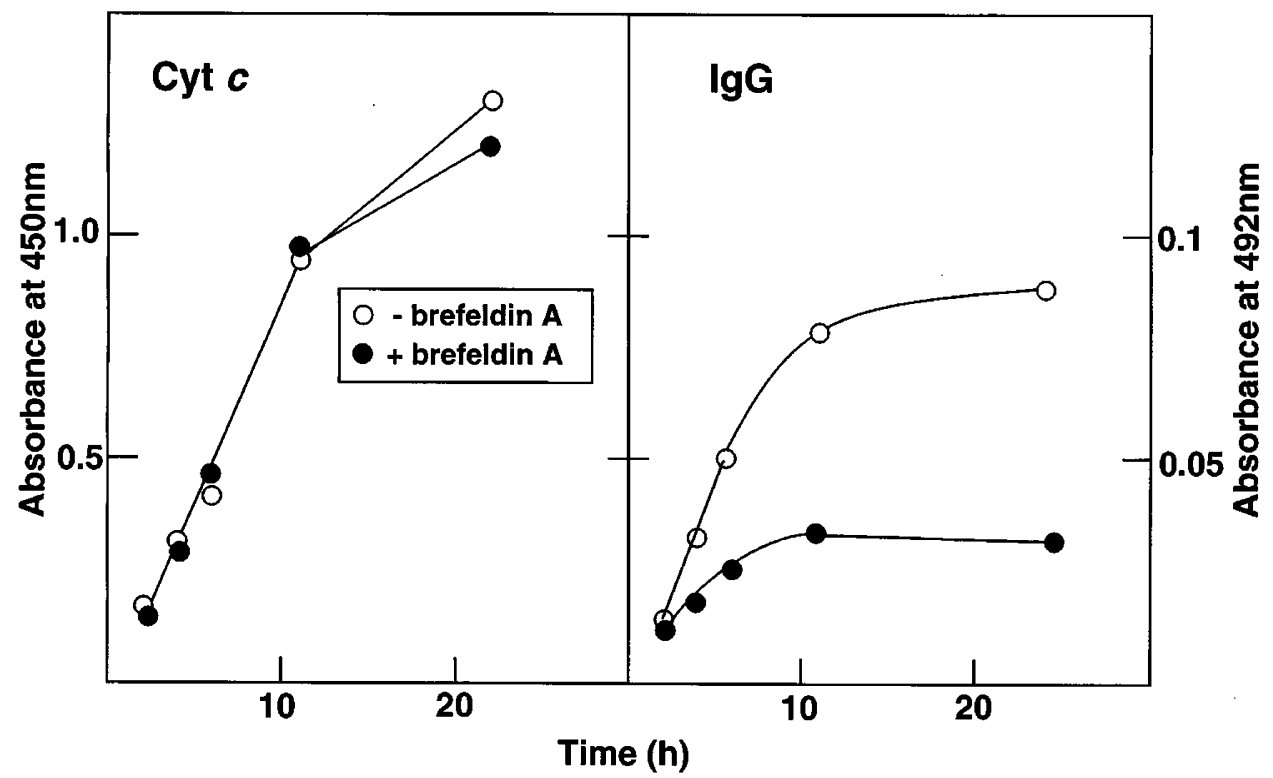

Figure 7 Effect of brefeldin A on the release of IgG but not Cyt $\mathrm{C}$ from mouse splenocytes deprived of serum. Cells $\left(5 \times 10^{7} / \mathrm{ml}\right)$ were incubated at $37^{\circ} \mathrm{C}$ with or without $0.5 \mu \mathrm{g} / \mathrm{ml}$ brefeldin A. Cyt $c$ released from the cells was measured by sandwich ELISA. IgG was measured by adsorbing $50 \mu \mathrm{l}$ culture fluid (1:24 dilution) to a microtiter plate and determining the IgG bound using horseradish peroxidase-labeled goat anti-mouse IgG in indirect ELISA. The values given are averages of duplicate values after the subtraction of the background reading
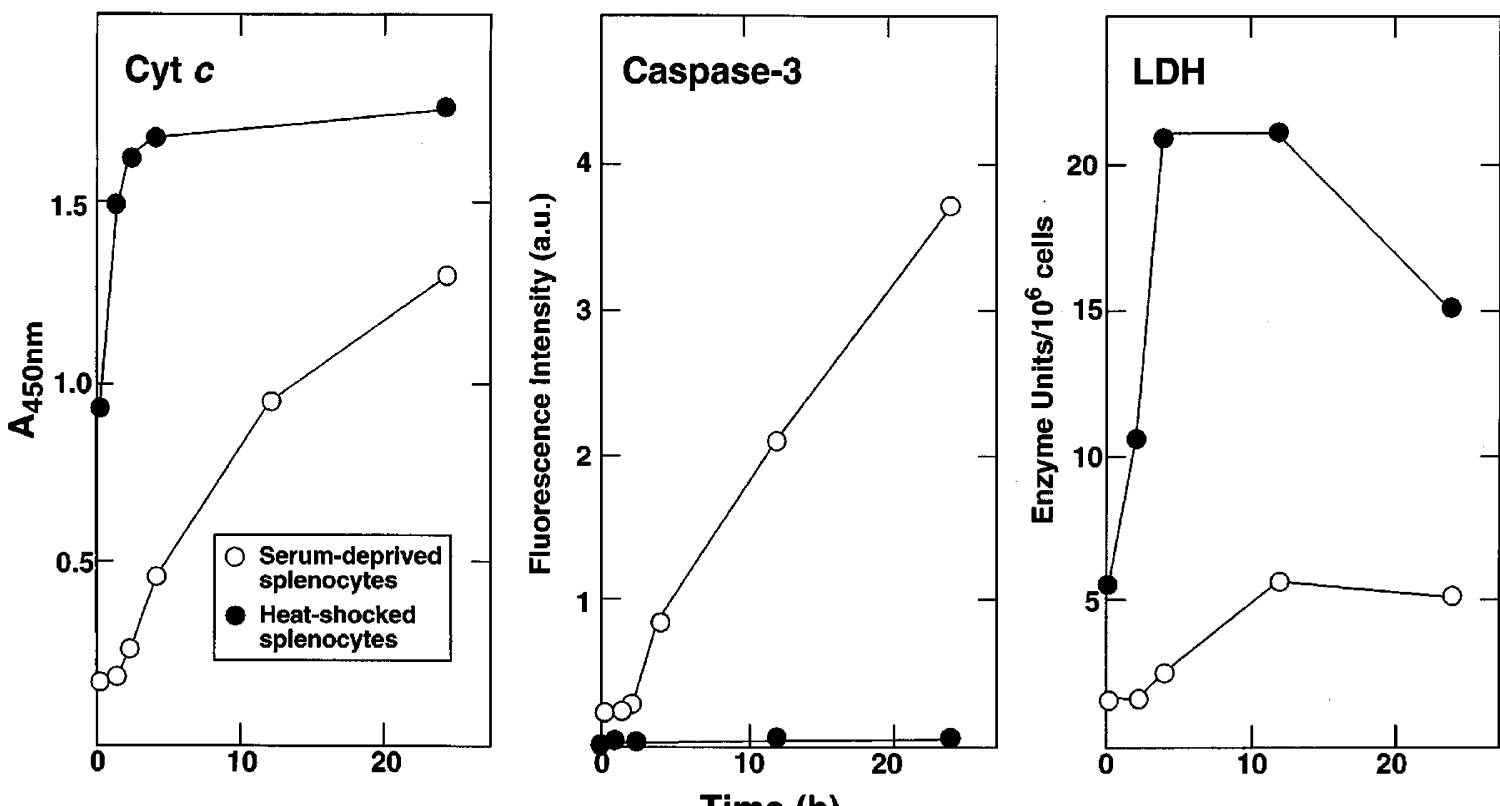

Time (h)

Figure 8 Release of Cyt c, caspase-3, and LDH from apoptotic and necrotic cells. Cyt $c$ present in the culture fluid was assessed by ELISA. Caspase-3 and LDH were assessed by their enzyme activity. The values for Cyt $c$ and for caspase-3 were determined in triplicate. LDH activity was determined from the averages of seven values obtained at $30 \mathrm{~s}$ intervals taken over a course of $4 \mathrm{~min}$. See Materials and Methods for details

substantial number of normal B lymphocytes react with annexin $\mathrm{V} .{ }^{19}$ Therefore, to compare the timing of Cyt $c$ release from apoptotic splenocytes with other apoptotic events, caspase-3 activity in whole cell lysates was studied at various times after culturing the cells in serum-free medium. Caspase- 3 is a key executioner in apoptosis. ${ }^{20}$ Its activity was quantified using a commercially-available kit which involves the cleavage of the substrate Z-DEVD-rhodamine 110 and the release of a fluorescent product.

Caspase-3 activity was detected in the apoptotic splenocytes at a substantial level as early as $1 \mathrm{~h}$ after the induction of apoptosis and was not quite maximal at $2 \mathrm{~h}$ 
after culture (Figure 6). In a second experiment (not shown) caspase- 3 activity was approximately half-maximal at $2 \mathrm{~h}$. Thus, the release of Cyt $c$ from apoptotic splenocytes began after the initiation of caspase- 3 activation and before it was complete (compare Figures 5 and 6).

\section{Cyt $c$ was not released from apoptotic splenocytes by active secretion}

To determine if Cyt $c$ may be secreted from cells undergoing apoptosis, splenocytes were treated with brefeldin A $(0.5 \mu \mathrm{g} /$ $\mathrm{ml}$ ) during culture in serum-free medium. At this concentration brefeldin A prevents secretion by blocking the transport of molecules from the endoplasmic reticulum to the Golgi network. ${ }^{21}$ There was no significant difference in the amount of Cyt $c$ released from cells cultured in the presence versus the absence of brefeldin A (Figure 7). In contrast, brefeldin A inhibited the secretion of mouse IgG from plasma cells present in the splenocyte preparation. These results indicate that Cyt $c$ is not released from apoptotic cells by active secretion.

\section{Release of other proteins from apoptotic and necrotic splenocytes}

To determine if there was selective release of Cyt $c$ relative to other intracellular proteins from apoptotic and necrotic splenocytes, the activities of two other proteins (caspase-3 and $\mathrm{LDH}$ ) were measured in the culture fluids (Figure 8). Caspase- 3 activity began to be observed in the culture fluid at $2 \mathrm{~h}$, increased at $4 \mathrm{~h}$, and continued to increase to $24 \mathrm{~h}$. The kinetics of caspase- 3 release from apoptotic cells were similar to the kinetics of the release of Cyt $c$. At $4 \mathrm{~h} 15 \%$ of total caspase-3 activity was released from the splenocytes and at $24 \mathrm{~h}$ this increased to $58 \%$ (calculated from the activity freed from apoptotic cells using $1 \%$ Triton $\mathrm{X}-100)$. This compares to 18 and $76 \%$ Cyt $c$ release from splenocytes at 4 and $24 \mathrm{~h}$, respectively. As the caspase- 3 activity increased in the culture fluid supernate the activity within the apoptotic splenocytes began to decline by $4 \mathrm{~h}$ and continued to decline beyond that time (results not shown). Caspase- 3 activity could not be detected in the supernates of necrotic cells since the enzyme was likely not rendered functional in the experimental conditions.

Another enzyme, LDH, which is known to be released from necrotic cells ${ }^{22,23}$ also began to be released from apoptotic cells between 2 and $4 \mathrm{~h}$, although the amount released from apoptotic cells was relatively low compared to the amount released from necrotic cells (Figure 8). The kinetics of $\mathrm{LDH}$ release from necrotic cells was similar to the kinetics of Cyt $c$ release even though the extent of LDH release was lower. The $\mathrm{LDH}$ activity released from necrotic cells represents the bulk of LDH in the cell as we determined the concentration of $\mathrm{LDH}$ to be approximately 20-30 units $/ 10^{6}$ viable splenocytes in three separate experiments.

\section{Discussion}

Previous reports suggested that after its translocation into the cytosol of apoptotic cells Cyt $c$ was degraded. ${ }^{7,8}$ This was based on its disappearance from the cytosol of late apoptotic cells visualized by immunofluorescence and from cytosolic extracts detected by Western blots. Here we showed that the disappearance of Cyt $c$ from both apoptotic and necrotic cells is due largely to its translocation from the interior of deathinduced cells into the culture medium and not to degradation. This was the case not only for two transformed cells studied, one of human origin and the other of mouse origin, but also for murine splenocytes obtained from two species. It appears that little, if any, Cyt $c$ was degraded since the amounts released from the cells and what remained cell-associated totaled approximately the same amount of Cyt $c$ that was extracted from live cells using detergent. Furthermore, no bands smaller than Cyt $c$ were detected in Western blots using a mAb reactive with the carboxyl terminal dodecapeptide indicating that the released Cyt $c$ was not even partially degraded during cell culture.

The Cyt $c$ that was released from all of these cells when death-induced, whether necrotic or apoptotic, was intact, monomeric, and native by several criteria. First, based on gel-filtration chromatography and Western blots the released Cyt $c$ was identical in size to native Cyt $c$. Second, the net charge of the released Cyt $c$ was identical to that of native Cyt $c$ based on its migration on a cation-exchange column. The eluting position of Cyt $c$ in ion-exchange chromatography is very sensitive to charge as evidenced by the effect of the single-charge difference between oxidized $\left(\mathrm{Fe}^{+3}\right)$ and reduced $\left(\mathrm{Fe}^{+2}\right)$ Cyt $c$ on the migration of the protein on the sulfopropyl column used in this study (result not shown). Simple removal of the $\mathrm{N}$-acetyl blocking group from the amino terminus, cleavage at the carboxyl terminal glutamic acid residue, modification would be sufficient to shift the eluting position of Cyt $c$. This indicates that Cyt $c$ released from apoptotic and necrotic cells is intact and native. Finally, in direct comparisons of the immunoreactivities of anti-Cyt $c$ mAbs in ELISA between native Cyt $c$ and Cyt $c$ released from apoptotic and necrotic cells, we observed no quantitative distinctions. Since mAbs specific for Cyt $c$ are known to be conformationally dependent, ${ }^{14,15}$ this indicates that Cyt $c$ released from death-induced cells was largely, if not entirely, native.

It is surprising that Cyt $c$ is not altered in apoptosis since many proteins are post-translationally modified in apoptotic cells. $^{24}$ For example, a number of proteins, including several that are targeted by antibodies in SLE, are crosslinked by transglutamination. ${ }^{25}$ Transglutaminase activity is actually increased in the cytoplasm of apoptotic cells. Cyt $c$ (human and mouse) contains five glutamine residues and 17 lysine residues (the common substrates for transglutaminase reactions) and is released into the cytoplasm early in apoptosis, yet we found no evidence for cross-linking as a fate of Cyt $c$. Although transglutamination prevents the leakage of cytosolic proteins from apoptotic cells, ${ }^{25}$ Cyt $c$ may be protected from this modification, perhaps, due to the role it plays in caspase activation.

The appearance of Cyt $c$ extracellularly as a monomer may also be unexpected since it associates with Apaf- 1 in the cytoplasm early in apoptosis. However, this interaction is not covalent and is, thus, dissociable. Furthermore, Cyt $c$ may well be in excess of Apaf-1 owing to its role in electron 
transport. It should be noted that Cyt $c$ was originally identified as a pro-apoptotic protein by its isolation from cytosol free of Apaf- $1 .^{3}$ Indeed, these molecules segregated into distinct fractions during their isolation so that observing Cyt $c$ as a monomer free from Apaf-1 outside of apoptotic cells should not be surprising.

Initiation of the release of Cyt $c$ from apoptotic splenocytes appears to occur at about the time that membrane perturbations would be expected to occur i.e., after Cyt $c$ translocation from the mitochondria to the cytosol leading to the activation of caspase-9 and, subsequently, caspase-3. Indeed, Cyt $c$ release from the cell (beginning 1.5-2 $\mathrm{h}$ after serum deprivation) must have initiated very soon after its translocation into the cytosol since caspase- 3 activity was still approaching the maximum when Cyt $c$ was detected in the culture fluid. In human B lymphocytes significant annexin $\mathrm{V}$ binding was not detected until after $2 \mathrm{~h}$ following serum-deprivation indicating that significant perturbations in the plasma membrane occur after caspase-3 activation. ${ }^{18}$

In contrast to splenocytes, transformed cells undergoing apoptosis were delayed in their release of Cyt $c$ which was observed only after perturbations in the plasma membrane. The distinction between normal and transformed cells in the kinetics of Cyt $c$ release may be due to differences in the plasma membrane. Indeed, different membrane potentials have been determined for normal versus transformed cells. ${ }^{26}$ Such a difference could also explain the delayed release of Cyt $c$ from necrotic transformed cells compared to splenocytes, despite the fact that similar numbers of normal and transformed cells were immediately rendered non-viable by heat shock as determined by their inability to exclude trypan blue.

It is widely held that cells early in apoptosis do not release their contents, presumably to protect against an inflammatory response. ${ }^{27}$ While the release of Cyt $c$ from necrotic cells and post-apoptotic cells may easily be understood as a consequence of damage to the plasma membrane, the mechanism by which Cyt $c$ is released relatively early from apoptotic cells (splenocytes) is not known. In this study, the extents of release of Cyt $c$ $(12.5 \mathrm{kDa})$ and caspase-3 (17-22 kDa) from apoptotic cells were similar, whereas the release of $\mathrm{LDH}(134 \mathrm{kDa})$ appeared to be less efficient suggesting an effect of size on the release of intracellular molecules. Perhaps, osmotic pressure increase in the apoptotic cells may allow intracellular molecules, particularly smaller ones, to escape while the cells can still exclude trypan blue. Cyt $c$ can rupture liposomes ${ }^{28}$ and this function may allow for it, and perhaps, other molecules to be released from cells once it is in the cytoplasm. Also, since Cyt $c$ is known to associate electrostatically with anionic phospholipids, ${ }^{29,30}$ their rearrangement in the membrane during apoptosis may allow displacement of Cyt $c$. As cell and membrane damage increases during the necrotic phase of cell death more Cyt $c$ may be released simply by diffusion. Cyt $c$ appears not to be translocated from apoptotic cells by active secretion. Brefeldin $A$, an inhibitor of secretion, had no effect on the accumulation of Cyt $c$ in the culture fluid of apoptotic cells.
The relatively rapid release of Cyt $c$ from apoptotic and necrotic splenocytes has implications for the etiology of systemic autoimmune diseases e.g., SLE, which involve antibody responses to intracellular antigens. Cyt $c$ has been shown to be a minor autoantigen targeted by antibodies in some patients with systemic autoimmunity. ${ }^{12}$ Since defects in phagocytosis affecting the clearance of apoptotic cells have been identified in patients with systemic autoimmunity, ${ }^{13}$ it is plausible that sufficient Cyt $c$ could be released from apoptotic cells in vivo to induce an antibody response in those individuals predisposed to autoimmunity. Severe necrosis may also result in the release of substantial amounts of Cyt $c$. Although it is possible that Cyt $c$ could be released normally from apoptotic cells in vivo, the amounts, if any, are likely to be small since most Cyt $c$-reactive B lymphocytes in mice are not rendered tolerant to mouse Cyt $c$. $^{31}$

\section{Materials and Methods}

\section{Cell culture}

Human HL-60 cells and mouse T-hybridoma (B3Z, a gift from Dr. Nilabh Shastri) cells were maintained in a $5 \% \mathrm{CO}_{2}$ incubator at $37^{\circ} \mathrm{C}$ in Dulbecco's modified Eagle's medium containing $15 \%$ fetal bovine serum and penicillin/streptomycin. Mouse and rat splenocytes were prepared from spleens by lysis of red blood cells in ACK Lysing Buffer (Biofluids Inc., Rockville, MD, USA) or by centrifugation through Histopaque-1077 (Sigma Chem. Co., St. Louis, MO, USA). Female $\mathrm{BALB} / \mathrm{c}$ mice (6 weeks old, strain $\mathrm{AnNCrlBr}$ ) were obtained from Charles River Breeding Laboratories (Wilmington, MA, USA). An adult Sprague-Dawley male rat was obtained from Harlan (Indianapolis, IN, USA).

\section{Induction of apoptosis and necrosis}

HL-60 cells were induced to apoptose by treatment with $1 \mu \mathrm{M}$ staurosporine or by $3000 \mathrm{R} \gamma$-irradiation from a Cesium source. Cells were induced to necrose by heat shock at $65^{\circ} \mathrm{C}$ for $5 \mathrm{~min}$. T-hybridoma cells were induced to apoptose by treatment with dexamethasone $(4 \mu \mathrm{g} / \mathrm{ml})$ or by $3000 \mathrm{R} \gamma$-irradiation. Splenocytes were induced to apoptose by serum deprivation (no serum supplement in the medium) and to necrose by heat shock. Following death induction, transformed cells were cultured at a density of $2.5 \times 10^{6} \mathrm{cells} / \mathrm{ml}(0.2 \mathrm{ml}$ per culture $)$ and splenocytes were cultured at a density of $5 \times 10^{7}$ cells $/ \mathrm{ml}$ unless otherwise noted. Cultures were harvested at various times following death induction. The cells were then centrifuged using a benchtop microfuge and the supernates were directly assayed for Cyt $c$. In some cases, the supernates were passed through a 0.2 micron filter (Costar, Corning, NY, USA) to remove insoluble debris. Cyt $c$ remaining in the cells was assayed following lysis in $1.0 \%$ Triton $\mathrm{X}-100$ in phosphatebuffered saline, $\mathrm{pH} 7.4$ (PBS).

\section{Protein quantification}

Human and mouse Cyt $c$ were quantified using commercially available ELISA kits (Quantikine M, R \& D Systems, Inc., Minneapolis, MN, USA) according to the manufacturer's instructions. When the Cyt $c$ present was found to saturate the assay plate, the culture fluids were diluted in PBS prior to assay. In experiments where triplicate values 
were obtained the standard deviations for Cyt $c$ quantification were generally less than $10 \%$ of the average values. Caspase- 3 activity in whole cell lysates $\left(3.5 \times 10^{6}\right.$ cells per sample) was determined using the EnzChek Caspase-3 Assay Kit \#2 (Molecular Probes) according to the manufacturer's instructions. Fluorescence of the product of the enzyme reaction was quantified using the FLUOstar Model 403 (BMG Lab Technologies, Durham, NC, USA) in Figure 6 or LS 55 Luminescent Spectrometer (Perkin-Elmer, Foster City, CA, USA) in Figure 8. Experimental values for caspase-3 activity were obtained in duplicate or in triplicate. In experiments where triplicate values were obtained the standard deviation averaged $11 \%$ of the mean. LDH was assayed by its catalytic activity. ${ }^{23}$ To $2 \mathrm{ml}$ PBS were added $100 \mathrm{ml}$ $\mathrm{NADH}(3 \mu \mathrm{g} / \mathrm{ml})$ and $100 \mathrm{ml}$ sodium pyruvate $(2.5 \mu \mathrm{g} / \mathrm{ml})$. After thorough mixing, $25-50 \mu$ l cell culture supernate or lysate was added and the decrease in absorbance at $340 \mathrm{~nm}$ was recorded every $30 \mathrm{~s}$ over the course of $4 \mathrm{~min}$. A unit of LDH activity is defined as a decrease of 0.001 absorbance units per min.

\section{Assays of plasma membrane integrity}

Perturbations in the plasma membrane of apoptotic transformed cells were assessed by annexin $\mathrm{V}$ binding using Alexa 488-annexin $\mathrm{V}$ (Molecular Probes, Eugene, OR, USA). Labeled cells were detected by flow cytometry using a FACScan (Becton-Dickinson, San Jose, CA, USA). Trypan blue uptake was determined as a measure of necrosis. ${ }^{33}$ Cells in culture medium were mixed with an equal volume $0.08 \%$ trypan blue and stained cells were counted using an inverted microscope and hemacytometer.

\section{Gel filtration chromatography}

For sizing of Cyt $c$ released from apoptotic and necrotic cells, transformed cells (approximately $5 \times 10^{8}$ ) were $\gamma$-irradiated or heat shocked then cultured for $16 \mathrm{~h}$ in $50-100 \mathrm{ml}$ DMEM without serum. Splenocytes were untreated or heat shocked then cultured without serum. The culture fluid was dialyzed twice against 3 I of $5 \mathrm{mM}$ ammonium bicarbonate and then lyophilized. The dried material was dissolved in $0.5 \mathrm{ml}$ PBS and applied to a $1.5 \times 50 \mathrm{~cm}$ column of Sephadex G-100 and eluted in PBS. The column was calibrated using rat immunoglobulin (purified in this laboratory), horse hemoglobin (Sigma Chem. Co. St. Louis, MO, USA), horse Cyt c (Sigma), and phenol red (Aldrich, Milwaukee, WI, USA). These molecules were detected spectrophotometrically as they eluted from the column. The fractions were assayed for Cyt $c$ by adsorbing $50 \mu \mathrm{l}$ of each fraction to a microtiter plate (Nunc Maxisorp, Gibco Scientific, Coon Rapids, MN, USA) and testing for Cyt $c$ immunoreactivity by ELISA. Binding of anti-Cyt $c$ mAbs to the microtiter plate was determined in indirect ELISA using goat antimouse IgG (whole molecule) conjugated to horseradish peroxidase (Sigma) and hydrogen peroxide/ophenylenediamine as substrate/ indicator in citrate-phosphate buffer pH 5.0.

\section{Western blotting}

Supernates of apoptotic and necrotic transformed cells were processed as described above and electrophoresed in a $15 \%$ polyacrylamide gel in sodium dodecylsulfate. Supernates of cultured splenocytes were directly applied to the gel. Proteins were electrophoretically transferred to Immobilon $\mathrm{P}$ membranes (Millipore Corp., Milford, MA, USA), then the blot was probed with mAb 7H8.2C12 (1:500 dilution of ascites fluid). Sheep anti-mouse IgG and Enhanced Chemiluminescence (Amersham Pharmacia Biotech, Piscataway, NJ, USA) were used to detect the mAb bound to Cyt $c$. The rat Cyt $c$ standard for Western blots was obtained from Sigma and the human Cyt $c$ standard was obtained from $R$ \& D Systems.

\section{High performance liquid cation-exchange chromatography}

Cyt $c$ was also fractionated from supernates of serum-free deathinduced cell cultures using a $7.5 \times 75 \mathrm{~mm}$ sulfopropyl (SP 5PW) column (Waters Division, Millipore Corp.) and HPLC. ${ }^{34}$ The supernates were dialyzed against $5 \mathrm{mM}$ ammonium bicarbonate, lyophilized to dryness, and dissolved in $0.5 \mathrm{ml} 10 \mathrm{mM}$ sodium phosphate $\mathrm{pH} 7.0$. A $0.2 \mathrm{ml}$ sample was oxidized with potassium ferricyanide $(5 \mu \mathrm{l}$ of $10 \mathrm{mg} / \mathrm{ml}$ ) and applied to the column. Proteins were eluted in a gradient of $0-400 \mathrm{mM}$ sodium chloride in $10 \mathrm{mM}$ phosphate, $\mathrm{pH} 7.0$ over a time course of $50 \mathrm{~min}$ and were detected spectrophotometrically at $214 \mathrm{~nm}$. To determine the eluting fractions containing Cyt $c$, $50 \mu \mathrm{l}$ of each $1.0 \mathrm{ml}$ fraction were adsorbed to microtiter plates and assayed for anti-Cyt $c$ mAb binding by indirect ELISA as described above. Rat Cyt $c$ used as a standard was obtained from Sigma and human Cyt $c$ was a gift of Dr. Mark Manula, Yale University.

\section{Note added in proof}

While this manuscript was being reviewed a paper was published which demonstrated the release of Cyt $c$ from apoptotic but not from necrotic cells. ${ }^{35}$ The rapid release of Cyt $c$ from heat-shocked (necrotic) cells in the present study may have been facilitated by damage to the plasma membrane caused by the relatively high temperature.

\section{Acknowledgements}

This work was supported by grants from the Minnesota Medical Foundation and the National Institutes of Health (1R21-Al45090). We thank Tim Leonard for assistance in the preparation of the figures and Dr. Calvin Roff, R \& D Systems, Dr. Peter Plagemann, Dr. Nickolay Brustovetsky, and Mark Daniels, University of Minnesota, for valuable discussions.

\section{References}

1. Margoliash E and Schejter A (1996) Cytochrome c. Adv. Protein Chem. 21:113286

2. Pettigrew GW and Moor GR (1987) Cytochromes c: Biological Aspects. Berlin and Heidelberg, Germany: Springer-Verlag.

3. Liu X, Kim CN, Yang J, Jemmerson R and Wang X (1996) Induction of apoptotic program in cell-free extracts: Requirement for dATP and cytochrome $c$. Cell 86: $147-157$

4. Yang J, Liu X, Bhalla K, Kim CN, Ibrado AM, Cai J, Peng T-I, Jones DP and Wang $X$ (1997) Prevention of apoptosis by Bcl-2: Release of cytochrome $c$ from mitochondria blocked. Science 275: 1129-1132

5. Kluck RM, Bossy-Wetzel E, Green DR and Newmeyer DD (1997) The release of cytochrome cfrom mitochondria: A primary site for $\mathrm{Bcl}-2$ regulation of apoptosis. Science 275: $1132-1136$

6. Li P, Nijhawan D, Budihardjo I, Srinivasula SM, Ahmad M, Alnemri ES and Wang $X$ (1997) Cytochrome $c$ and dATP-dependent formation of Apaf-1/caspase- 9 complex initiates an apoptotic protease cascade. Cell 91: 479-489

7. Neame SJ, Rubin LL and Philpott KL (1998) Blocking cytochrome cactivity within intact neurons inhibits apoptosis. J. Cell Biol. 142: 1583-1593 
8. Bobba A, Atlante A, Giannattasio S, Sgaramella G, Calissano P and Marra E (1999) Early release and subsequent caspase-mediated degradation of cytochrome $c$ in apoptotic cerebellar granule cells. FEBS Lett 457: 126-130

9. Bell DA and Morrison B (1991) The spontaneous apoptotic cell death of normal human lymphocytes in vitro: the release of, and immunoproliferative response to, nucleosomes in vitro. Clin. Immunol. Immunopathol. 60: 13-26

10. Endrich MM, Grossenbacher D, Geistlich A and Gehring H (1996) Apoptosisinduced concomitant release of cytosolic proteins and factors which prevent cell death. Biol. Cell 88: 15-22

11. Huggins ML, Todd I, Cavers MA, Pavuluri SR, Tighe PJ and Powell RJ (1999) Antibodies from systemic lupus erythematosus (SLE) sera define differential release of autoantigens from cell lines undergoing apoptosis. Clin. Exp. Immunol. 118: 322-328

12. Mamula MJ, Jemmerson R and Hardin JA (1990) The specificity of human anticytochrome c autoantibodies that arise in autoimmune disease. J. Immunol. 144: $1835-1840$

13. Herrmann M, Voll RE, Zoller OM, Hagenhofer M, Ponner BB and Kalden JR (1998) Impaired phagocytosis of apoptotic cell material by monocyte-derived macrophages from patients with systemic lupus erythematosus. Arthritis and Rheumatism 41: 1241-1250

14. Goshorn SC, Retzel E and Jemmerson R (1991) Common structural features among monoclonal antibodies binding the same antigenic region of cytochrome c. J. Biol. Chem. 266: 2134-2142

15. Mueller CM and Jemmerson R (1996) Maturation of the antibody response to the major epitope on the self antigen mouse cytochrome $c$-restricted $V$ gene usage, selected mutations, and increased affinity. J. Immunol. 157: 5329-5338

16. Jemmerson R, Johnson JG, Burrell E, Taylor PS and Jenkins MK (1991) A monoclonal antibody specific for a cytochrome $c$ T cell stimulatory peptide inhibits $T$ cell responses and affects the way the peptide associates with antigenpresenting cells. Eur. J. Immunol. 21: 143-151

17. Fadok VA, Voelker DR, Campbell PA, Cohen JJ, Bratton DL and Henson PM (1992) Exposure of phosphatidylserine on the surface4 of apoptotic lymphocytes triggers specific recognition and removal by macrophages. J. Immunol. 148 : $2207-2216$

18. Koopman G, Reutelingsperger CP, Kuijten GA, Keehnen RM, Pals ST and van Oers MH (1994) Annexin $V$ for flow cytometric detection of phosphatidylserine expression on $B$ cells undergoing apoptosis. Blood 84: 1415-1420

19. Dillon SR, Mancini M, Rosen A and Schlissel MS (2000) Annexin V binds to viable $B$ cells and colocalizes with a marker of lipid rafts upon $B$ cell receptor activation. J. Immunol. 164: 1322-1332
20. Zheng TS, Hunot S, Kuida K and Flavell RA (1999) Caspase knockouts: Matters of life and death. Cell Death Differ. 6: 1043-1053

21. Yewdell JW and Bennink JR (1989) Befeldin A specifically inhibits presentation of protein antigens to cytotoxic T lymphocytes. Science 244: 1072-1075

22. Henley KS, Schmidt E and Schmidt FW (1960) Serum enzymes. JAMA 174: $119-123$

23. Wells IC (1969) Release of intracellular enzymes into serum. Can. J. Biochem. 47: $347-351$

24. Hale AJ, Smith CA, Sutherland LC, Stoneman VEA, Longthorne VL, Culhane AC and Williams GT (1996) Apoptosis: molecular regulatin of cell death. Eur. J. Biochem. 236: 1-26

25. Piacentini M and Colizzi V (1999) Tissue transglutaminase: apoptosis versus autoimmunity. Immunol. Today 20: 130-134

26. Stern RG, Milestone BN and Gatenby RA (1999) Carcinogenesis and the plasma membrane. Medical Hypotheses 52: 367-372

27. White $E$ (1996) Life, death and pursuit of apoptosis. Genes Dev. 10: 1-15

28. Tuominen EKJ, Wallace CJA and Kinnunen PKJ (1997) The invariant $A R G^{91}$ is required for the rupture of liposomes by cytochrome $c$. Biochem. Biophys. Res. Comm. 238: 140-142

29. Nicholls $P$ and Malviya AN (1973) External and internal binding of cytochrome $c$ by liposomes. Biochem. Soc. Trans. 1: 372-375

30. Hildebrandt P, Heimburg T and Marsh D (1990) Quantitative conformational analysis of cytochrome $c$ bound to phospholipid vesicles studied by resonance Raman spectroscopy. Eur. Biophys. J. 18: 193-201

31. Jemmerson R and Blankenfeld R (1988) Clonal analysis of the BALB/C secondary B cell repertoire specific for a self antigen, cytochrome $c$. J. Immunol. 140: $1762-1769$

32. Sanderson S and Shastri N (1993) LacZ inducible, antigen/MHC-specific T cell hybrids. Inter. Immunol. 6: 369-376

33. Koester SK and Bolton WE (1999) Differentiation and assessment of cell death. Clin. Chem. Lab. Med. 37: 311-317

34. Koshy TI, Luntz TL, Garber EAE and Margoliash E (1992) Expression of recombinant cytochromes cfrom various species in Saccharomyces cerevisiae: post-translational modifications. Protein Expr. Purif. 3:441-452

35. Renz A, Berdel WE, Kreuter M, Belka C, Schulze-Osthoff K and Los M (2001) Rapid extracellular release of cytochrome $\mathrm{c}$ is specific for apoptosis and marks cell death in vivo. Blood 98: 1542-1548. 